\title{
ALPINE MOIST MEADOW RESPONSE TO NITROGEN DEPOSITION IN THE GREATER YELLOWSTONE ECOSYSTEM
}

\author{
AMBER C. CHURCHILL $\uparrow$ WILLIAM D. BOWMAN $\uparrow$ UNIVERSITY OF COLORADO \\ BOULDER, CO
}

\begin{abstract}
$\uparrow$ ABSTRACT
The deposition of anthropogenic reactive nitrogen $(\mathrm{N})$ in alpine ecosystems can have multiple deleterious effects on plants, soils and hydrology in both the alpine and areas downstream through leaching and export. Thresholds for ecological responses to $\mathrm{N}$ deposition have been established for lakes, soils and changes in plant community composition in some areas of the Rocky Mountains. These thresholds offer a target for land and air resource managers to prevent significant changes in ecosystem function, however the underlying feedbacks controlling ecosystem response have not been fully examined. Research originally proposed in association with our UW NPS Small Grant aimed to examine plant to ecosystem interactions within alpine moist meadows between two sites receiving different levels of $\mathrm{N}$ deposition. This focus has been modified, in response to site limitations, to examine the mediation of the $\mathrm{N}$ cycle by the alpine moist meadow plant community.
\end{abstract}

\section{$\uparrow \quad$ INTRODUCTION}

Human alteration of the nitrogen $(\mathrm{N})$ cycle has resulted in a drastic change in availability of biologically active $\mathrm{N}$, in both human-dominated and natural landscapes (Vitousek et al. 1997). This increased availability has translated into high rates of deposition in regions with expanding populations of people, and widespread changes in land use, such as areas in the central Rocky Mountains (Baron et al. 2000, Matson et al. 2002, Benedict et al. 2013). Alpine ecosystems are particularly susceptible to increased inputs of $\mathrm{N}$, as higher elevations receive disproportionately more precipitation (Weathers et al. 2000, Williams and Tonnessen 2000), making the alpine of the southern Rocky Mountains an ideal location for studying ecosystem responses and processes under elevated $\mathrm{N}$ deposition. The Rocky Mountains on the western side of the Continental Divide in Wyoming receive enhanced deposition associated with emissions of nitrogen from agricultural sources, while the eastern side has comparatively low levels of ambient deposition (Figure 1; Van Miegroet 2010, Nanus et al. 2003). By comparing the same alpine meadow communities in these mountain regions, our goal was to estimate the existing effects of $\mathrm{N}$ deposition in the alpine ecosystem, and compare community level plant-soil feedbacks.

There are many environmental consequences associated with increased $\mathrm{N}$ deposition, ranging from ecosystem scale changes in function and services, to local scale changes in diversity of the plant community. The level of $\mathrm{N}$ addition necessary to induce environmental consequences, or the ecological threshold, varies between different measures of response and provides a metric of stability for comparing how well that ecosystem is able to stabilize added N. At the community level, numerous studies in the Rocky Mountain alpine have shown that even levels of $\mathrm{N}$ deposition at or below $4 \mathrm{~kg} \mathrm{~N} \mathrm{ha}^{-1} \mathrm{yr}^{-1}$ 
significantly alters species composition in dry meadows (Bowman et al. 2006, 2012). At the ecosystem scale, research in dry meadows has shown that $\mathrm{N}$ deposition levels greater than $20 \mathrm{~kg} \mathrm{~N} \mathrm{ha}^{-1} \mathrm{yr}^{-1}$ was sufficient to induce increases in nitrate leaching (Bowman et al. 2006).

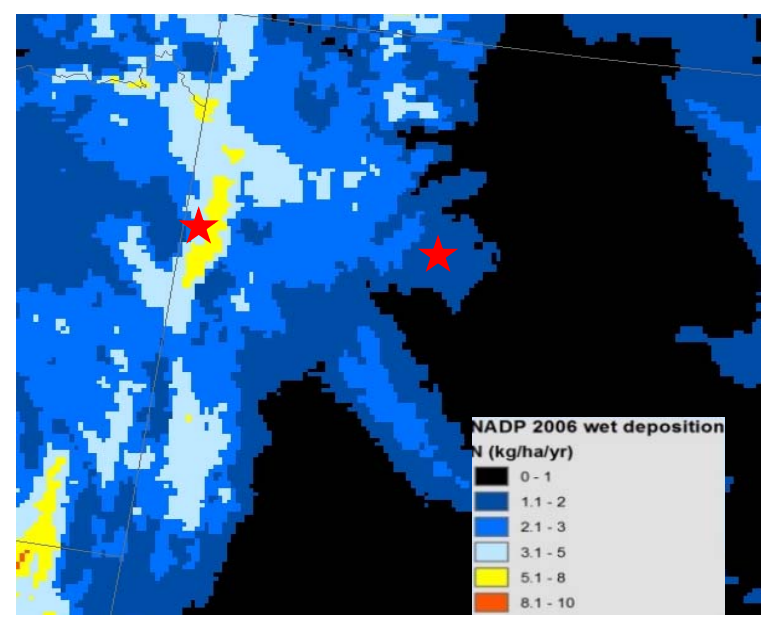

Figure 1. Nitrogen deposition in the Greater Yellowstone Ecosystem of Wyoming, with field sites in this study marked by red stars. The site in Shoshone NF was established in the summer of 2012 and maintained in the summer of 2013. We were unable to establish the GRTE site as planned, due to lack of similarity in plant composition in the alpine between these regions.

Factors contributing to potential differences in ecosystem thresholds, however, include biological changes and feedbacks within an ecosystem. There are three main pathways for plants to influence ecosystem response, including 1) species-level variation in $\mathrm{N}$ uptake (Hobbie 1992, Suding et al. 2004, Ashton et al. 2008), 2) storage of nutrients in plant tissue (Bowman et al. 1993, Bowman 1994, Chapin et al. 1997), and 3) loss of $\mathrm{N}$ in litter (Hobbie 1992, Steltzer and Bowman 1998, Chapman et al. 2006). While these processes occur at the level of individual plant species, for processes happening at the ecosystem scale it is net plant community contributions that ultimately contribute to subsequent ecosystem responses to $\mathrm{N}$ deposition. Understanding the net community response $\mathrm{N}$ deposition informs predictions of ecosystem responses to $\mathrm{N}$ deposition that take into account internal biological feedbacks. These biotic contributions may provide positive (amplifying) or negative (stabilizing) feedbacks to changes in the environment (Hobbie 1992, Chapin et al. 1997). Stabilizing feedbacks minimize changes in ecosystem while amplifying feedbacks can intensify the effects of environmental change (Chapin et al. 2010).

Under the context of $\mathrm{N}$ deposition to alpine ecosystems, characteristics of plants with biotic stabilizing feedbacks to $\mathrm{N}$ deposition may include traits that increase storage of $\mathrm{N}$ in plant tissues, and litter with high C:N ratios (Steltzer and Bowman 1998, Bowman 2000). Another mechanism possibly mitigating the impact of $\mathrm{N}$ deposition is the immobilization of $\mathrm{N}$ in soil or recalcitrant materials, thereby limiting the leaching of nitrate (Janssens et al. 2010). On the other hand, community traits that amplify the effects of $\mathrm{N}$ deposition within an ecosystem may include increased rates of $\mathrm{N}$ cycling through stimulated productivity rates with a greater input of $\mathrm{N}$ rich litter into the soil (low $\mathrm{C}: \mathrm{N}$ ratios) or increased $\mathrm{N}$ turnover in tissues (higher rates of decomposition) and soil (both from deposition and increased herbivory) (Bowman and Steltzer 1998, Throop 2005). These characteristics would facilitate an increase in $\mathrm{N}$ availability for plants and microbes, increases in nitrification, and ultimately the loss of 'extra' $\mathrm{N}$ from the alpine due to increased nitrate mobility.

Estimation of the thresholds for the amount of nitrogen addition that causes changes to vegetation and soils are a common research goal across the National Park Service, and previous studies have estimated critical load values for $\mathrm{N}$ deposition in alpine lakes, and alpine plant communities and soils at ROMO (Baron 2006, Bowman et al. 2006, 2012). Continued research is expanding this concept into GRTE, and the Greater Yellowstone Ecosystem, with implications for management and long-term data comparison (Van Miegroet 2010, Pardo et al. 2011, Hansen 2012). Our research questions for this project were 1) do differences in ambient $\mathrm{N}$ deposition gradient translate into differences in ecosystem $\mathrm{N}$ availability and coupled changes in plant community indices? And 2) are plant contributions to nitrogen storage and cycling the same between east and west slopes or do they change with levels of $\mathrm{N}$ addition?

\section{$\uparrow \quad$ STUDY AREA}

Original study design included two research sites: one in an area of low $\mathrm{N}$ deposition (Shoshone National Forest) and the second in an area of high $\mathrm{N}$ deposition (Grand Teton National Park; GRTE) (Nanus et al. 2003). Proposed site locations were selected based upon estimated levels of ambient $\mathrm{N}$ deposition (low and high) on federally protected land within the Greater Yellowstone Ecosystem (Figure 1). Site positioning at Shoshone National Forest was completed during the summer of 2012, with a goal of establishing a field site in GRTE in the summer of 2013. 
The field site at Shoshone National Forest (NF) included three alpine moist meadows, each with a slope $<15 \%$. Average elevation at this site is $3200 \mathrm{~m}$, and the site position is $43.930061 \mathrm{~N}, 109.2930157 \mathrm{~W}$. The area used for research is located NE of the Meadow Creek Trail in the Greybull Ranger District of Shoshone NF.

Despite repeated attempts to locate appropriate alpine meadow communities in GRTE during the summer of 2013 (and 2012); no area was found that met the study site requirements for comparable plant composition, including the main two dominant moist meadow plant species (Geum rossi and Deschampsia caespitosa). Areas surveyed included Mount Meek Pass, Alaska Glacier Basin, and Rendezvous Peak during visits in July and August 2013. While the exclusion of this site limits the comparison between areas receiving different levels of $\mathrm{N}$ deposition in the Greater Yellowstone Ecosystem, we have four other established sites in the Rocky Mountains of Colorado supported through other sources of funding, which will allow the existing site to be of importance in addressing related questions and hypotheses.

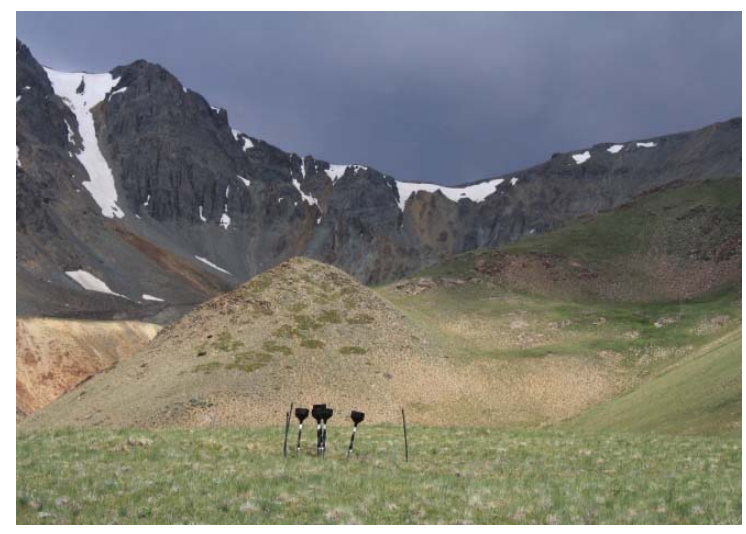

Figure 2. Nitrogen deposition samplers installed in the field at Shoshone National Forest

\section{$\uparrow \quad$ METHODS}

\section{Site based measurements}

The summer/growing season bulk deposition of nitrogen $(\mathrm{N})$ was measured passively at Shoshone $\mathrm{NF}$ using ion-exchange mixed bead resin columns installed for at least 60 days (Bytnerowicz et al. 2001, Fenn et al. 2009, Hansen 2012). Five samplers were installed at the site per summer (Figure 2), and total deposited $\mathrm{N}$ was determined using $2 \mathrm{M} \mathrm{KCl}$ extraction of the sampler resin and analyzing for $\mathrm{NH}_{4}{ }^{+}-\mathrm{N}$ and $\mathrm{NO}_{3}{ }^{-}-\mathrm{N}$ in the Kiowa Chemistry Laboratory at
INSTAAR, using a Lachat QuikChem 8000 Spectophoto-metric Flow Injection Analyzer and a Dionex DX 500 System IonPac AS11 Ion Chromatograph (Sunnyvale, California, USA) (Bowman et al. 2006).

Climate data was extracted from PRISM to examine annual differences in precipitation between years of study (2012-2014), and local weather data will be determined from neighboring climate stations.

\section{Soil measurements}

We measured soil $\mathrm{N}$ availability using mixed bead resin bags buried in the plant rooting zone during growing season months (five resin bags per meadow). We also measured soil water nitrate concentration, an indication of mobile inorganic $\mathrm{N}$ in soil, using lysimeters and vacutainers installed at each of the five plots in each meadow (Figure 3). Soil water samples were attempted during three periods during the growing season, including post snow melt, peak growing season and following plant senescence (Bowman et al. 2012), however no water was successfully sampled using the vacutainers during 2013. Finally, bulk soil samples (10 per meadow) were used to determine relative abundance of $\mathrm{N}$ in soil using $\mathrm{C}: \mathrm{N}$ ratios, soil $\mathrm{pH}$ and soil cation exchange capacity.

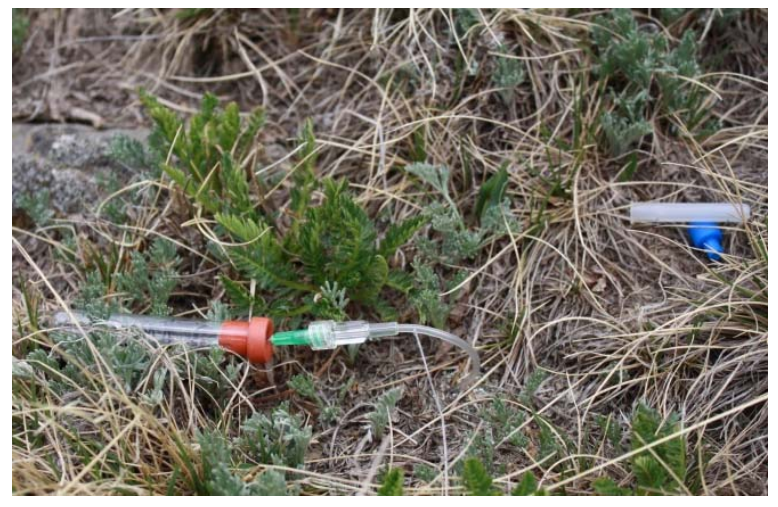

Figure 3. Soil lysimeter and attached vacutainer collecting soil water for analysis of mobile N (nitrate).

\section{Vegetation measurements}

We used the point intercept method to quantify species composition in moist meadows at Shoshone NF (data collected 2012-2013; Jonasson 1988). For this method, we measured 20 plots in each moist meadow (4 meadows) in the summer of 2012, and 10 plots per meadow ( 3 meadows) in the summer of 2013. Vegetation plots were $1 \mathrm{~m}$ by $1 \mathrm{~m}$ in area. 
For determining total aboveground biomass, we harvested total standing vegetation in $10 \mathrm{~cm}$ by 10 $\mathrm{cm}$ subplots at peak biomass in the summer of 2012 . We plan to specifically target measurement of net primary productivity (annual new growth) collection at peak biomass in the summer of 2014 using the same in-field procedure. This sample harvest will be followed by separation of new and old material in the laboratory.

We also collected plant tissue samples for determining tissue concentrations of $\mathrm{C}: \mathrm{N}$ for dominant and sub-dominant species at each plot for tissue at peak plant biomass (10 samples per meadow all species 2012, dominants only 2013). Litter collection of dominant species within each meadow will also be performed post senescence to estimate $\mathrm{N}$ input to the soil at the end of the growing season (10 samples per meadow; data collected 2014).

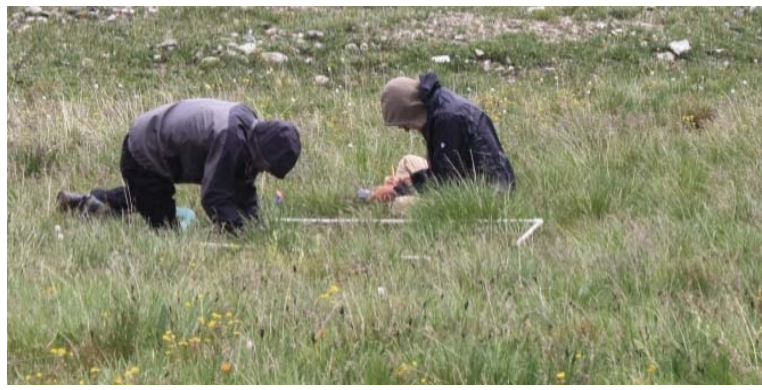

Figure 4. Crew measuring vegetation presence and abundance.

\section{$\downarrow \quad$ PRELIMINARY RESULTS}

\section{Site scale data}

$\mathrm{N}$ deposition at Shoshone NF during the summer of 2012 totaled $0.24 \pm 0.08 \mathrm{~kg} \mathrm{~N} \mathrm{ha}^{-1}$ over a 92 day growing season (June $1^{\text {st }}$ - August $31^{\text {st }}$ ). Results from the summer of 2013 are still being analyzed at the KIOWA laboratory at the University of Colorado Boulder, and should be completed by April 2014.

We are still in the process of downloading and analyzing associated climate data from years 2012-2014.

\section{Soil data}

Soil samples collected at Shoshone NF during the summer of 2012 were found to have an average $\mathrm{pH}$ of $5.33( \pm 0.08 \mathrm{SE})$ and a cation exchange capacity (CEC) of $21.47( \pm 1.07 \mathrm{SE}) \mathrm{cmol}_{\mathrm{c}} / \mathrm{kg}$, indicating well buffered soils. Dominant cations included $\mathrm{Ca}^{+}$and $\mathrm{Mg}^{+}$(77 and 18 percent of total CEC, respectively), with trace amounts of other cations measured $\left(\mathrm{Al}^{+3}, \mathrm{Fe}^{+2}, \mathrm{Mn}^{+2}\right.$, and $\left.\mathrm{Na}^{+}\right)$.

Measurements for concentrations of mobile $\mathrm{N}$ (nitrate) in soil water were unsuccessful during the summer of 2013 due to very dry soils throughout the summer. No water was consequently collected despite three attempts and attempts to maintain vacutainers on soil lysimeters for over 24 hours. We plan on making an earlier attempt during the summer of 2014, to include post snowmelt moisture.

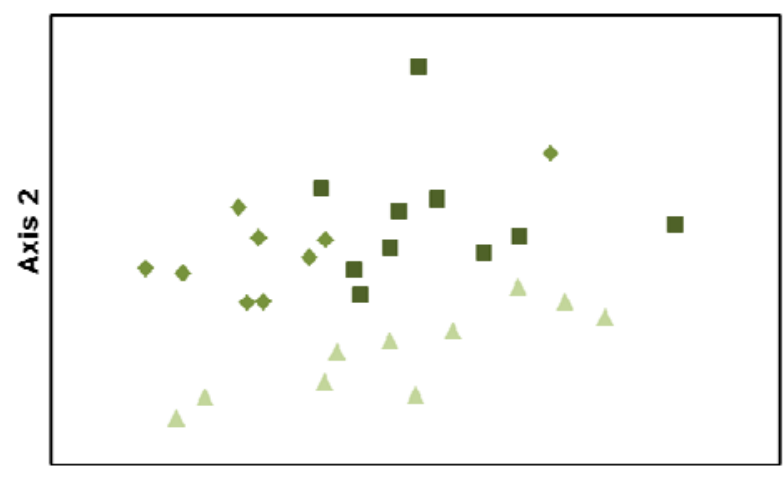

Axis 1

Figure 5. Non-metric dimensional scaling ordination of the plant community composition between three alpine moist meadows at Shoshone NF (each meadow is represented in a different shade of green). Two axes accounted for $85.3 \%$ of total variation in composition between plots in each meadow.

Remaining soil data, including measurements of growing season $\mathrm{N}$ availability using ion-exchange resin bags, and soil ratios of carbon to $\mathrm{N}$, are on schedule for being completed by May 2014.

\section{Vegetation data}

Aboveground biomass of vegetation among the moist meadows at Shoshone NF averaged 2.2 $\mathrm{kg} / \mathrm{m}^{2}( \pm 0.12 \mathrm{SE})$. The total species richness was 17.1 species $/ \mathrm{m}^{2}( \pm 0.41 \mathrm{SE})$, and the Shannon Diversity Index was $2.02( \pm 0.03 \mathrm{SE})$ across the three moist meadows.

Non-metric dimensional scaling ordination was able to describe the plant community composition in two axes (Axis $1=58.5 \%$ variation, Axis $2=26.8 \%$ variation, with a final stress of 15.12 , and a final instability of $<0.00000$ (Figure 5). Axis 1 was correlated with the presence of Carex elynodes $\left(\mathrm{r}^{2}=\right.$ $0.83)$, an as-of-yet-unidentified legume forb $\left(\mathrm{r}^{2}=0.52\right)$ and Geum rossii $\left(\mathrm{r}^{2}=0.5\right)$. Axis 2 was correlated with an unknown sedge $\left(r^{2}=0.76\right)$, and a different unknown forb $\left(r^{2}=0.35\right)$. Future analysis will examine environmental correlations with community 
composition of individual plots, including soil $\mathrm{N}$ availability, $\mathrm{C}: \mathrm{N}, \mathrm{pH}, \mathrm{CEC}$, and soil water nitrate, as well as the relationship of dominant plant types on soil $\mathrm{N}$ pools.

Dominant and sub-dominant plant tissue concentrations of carbon and $\mathrm{N}$ are still being determined using elemental analysis, and are on target for completion by May 2014.

\section{Future data collection}

Supplemental data associated with the Shoshone NF site is planned for collection during the summer of 2014 to address some of the remaining potential feedbacks within the alpine ecosystem components. This will include collections of the net primary productivity of the vegetation at peak biomass (early August) to estimate the annual storage of $\mathrm{N}$ in the plant tissue, and plant litter following senescence in the fall. We will also collect soil samples for determining soil texture (percent sand, silt, clay) to differentiate possible soil controls on vegetation that may affect the interpretation of our existing data. Finally, we plan to continue collecting samples in an attempt to measure soil nitrogen mobility using lysimeters and attached vacutainers for collecting soil water samples for nitrate concentration analysis.

\section{MANAGEMENT IMPLICATIONS}

Although we were unable to implement our full project through the installation of a field site in Grand Teton National Park, we have successfully collected most of our proposed samples from Shosone $\mathrm{NF}$, and plan to visit this site again in the summer of 2014. The grant money awarded our project for the year 2013-2014 was instrumental in the success of collecting those data, and has allowed us to gain additional in-house support to maintain this field site for data collection into the coming year. We will also be able to successfully incorporate the Shoshone site into a larger scale regional study of $\mathrm{N}$ deposition in the Rocky Mountains, which will ultimately contribute to two dissertation chapters of A. Churchill.

At this time many of our statistical analyses are preliminary, as soil and vegetation samples are in the process of chemical analysis, and we are waiting on these results before moving forward. These samples are on schedule for completion in the coming months, and we anticipate that our first publication using these data will be written during the fall of 2014. It is our hope that these results will offer regional conclusions about $\mathrm{N}$ deposition in the Rocky Mountains and the GYE, and offer increased information on the internal feedbacks between plants and $\mathrm{N}$ processes in alpine moist meadows.

\section{ACKNOWLEDGEMENTS}

In addition to support from the UW-NPS Research Station, this project has received key funding from the NPS George Melendez Wright Climate Change Youth Initiative Fellowship, the Department of Ecology and Evolutionary Biology at the University of Colorado Boulder, the Graduate School at University of Colorado Boulder, the BURST and UROP undergraduate training programs at the University of Colorado Boulder and the John Marr Ecology research grant. Design and coordination of the study has benefited from the support of Matt Ribarich, Drew Meyers (BURST), George Libby (UROP), Colin Luben (UROP), Jeff Neiman (UROP) and Peter Omasta (UROP).

\section{LITERATURE CITED}

Ashton, I. W., A. E. Miller, W. D. Bowman, and K. N. Suding. 2008. Nitrogen preferences and plant-soil feedbacks as influenced by neighbors in the alpine tundra. Oecologia 156: 625-636.

Baron, J. S. 2006. Hindcasting nitrogen deposition to determine an ecological critical load. Ecological Applications 16: 433-439.

Baron, J. S., H. M. Rueth, A. M. Wolfe, K. R. Nydick. E. J. Allstott, J. T. Minear, and B. Moraska. 2000. Ecosystem responses to nitrogen deposition in the Colorado Front Range. Ecosystems 3: 352-368.

Benedict, K. B., D. Day, F. M. Schwandner, S. M. Kreidenweis, B. Schichtel, W. C. Malm, and J. L. Collett Jr. 2013. Observations of atmospheric reactive nitrogen species in Rocky Mountain National Park and across northern Colorado. Atmospheric Environment 64: 66-76.

Bowman, W. D. 1994. Accumulation and use of nitrogen and phosphorus following fertilization in two alpine tundra communities. Oikos 70: 261-270.

Bowman, W. D. 2000. Biotic controls over ecosystem response to environmental change in alpine tundra of the Rocky Mountains. AMBIO: A Journal of the Human Environment 29: 396400. 
Bowman, W. D., and H. Steltzer. 1998. Positive feedbacks to anthropogenic nitrogen deposition in Rocky Mountain alpine tundra. Ambio 27: 514-517.

Bowman, W. D., T. A. Theodose, J. C. Schardt, and R. T. Conant. 1993. Constraints of nutrient availability on primary production in two alpine tundra communities. Ecology 74: 2085-2097.

Bowman, W. D., J. R. Gartner, K. Holland, and M. Wiedermann. 2006. Nitrogen critical loads for alpine vegetation and terrestrial ecosystem response: Are we there yet? Ecological Applications 16: 1183-1193.

Bowman, W. D., J. Murgel, T. Blett, and E. Porter. 2012. Nitrogen critical loads for alpine vegetation and soils in Rocky Mountain National Park. Journal of Environmental Management 103: 165-171.

Bytnerowicz, A., P. E. Padgett, M. J. Arbaugh, D. R. Parker, and D. P. Jones. 2001. Passive sampler for measurement of atmospheric nitric acid vapor $\left(\mathrm{HNO}_{3}\right)$ concentrations. The Scientific World Journal 1: 815-822.

Chapin, F. S., B. H. Walker, R. J. Hobbs, D. U. Hooper, J. H. Lawton, O. E. Sala, and D. Tilman. 1997. Biotic control over the functioning of ecosystems. Science 277: 500-504.

Chapin, F. S., A. D. McGuire, R. W. Ruess, T. N. Hollingsworth, M. C. Mack, J. F. Johnstone, and D. L. Taylor. 2010. Resilience of Alaska's boreal forest to climatic change. Canadian Journal of Forest Research 40: 1360-1370.

Chapman, S. K., J. A. Langley, S. C. Hart, and G. W. Koch. 2006. Plants actively control nitrogen cycling: Uncorking the microbial bottleneck. New Phytologist 169: 27-34.

Fenn, M. E., J. O. Sickman, A. Bytnerowicz, D. W. Clow, N P. Molotch, J. E. Pleim, and D. H. Campbell. 2009. Methods for measuring atmospheric nitrogen deposition inputs in arid and montane ecosystems of western North America. Developments in Environmental Science 9: 179-228.

Hansen, J. 2012. Assessment of atmospheric nitrogen deposition: Possible effects on alpine ecosystems above 9000 feet in Grand Teton National Park. 184 pp.

Hobbie, S. E. 1992. Effects of plant species on nutrient cycling. Trends in Ecology and Evolution 7: 336-339.
Janssens, I. A., W. Dieleman, S. Luyssaert, J. A. Subke, M. Reichstein, R. Ceulemans, and B. E. Law. 2010. Reduction of forest soil respiration in response to nitrogen deposition. Nature Geoscience 3: 315-322.

Jonasson, S. 1988. Evaluation of the point intercept method for the estimation of plant biomass. Oikos 52: 101-106.

Matson, P., K. A. Lohse, and S. J. Hall. 2002. The globalization of nitrogen deposition: Consequences for terrestrial ecosystems. AMBIO: A Journal of the Human Environment 31: 113-119.

Nanus, L., D. H. Campbell, G. P. Ingersoll, D. W. Clow, and M. A. Mast. 2003. Atmospheric deposition maps for the Rocky Mountains. Atmospheric Environment 37: 4881-4892.

Pardo, L. H., M. E. Fenn, C. L. Goodale, L. H. Geiser, C. T. Driscoll, E. B. Allen, and R. L. Dennis. 2011. Effects of nitrogen deposition and empirical nitrogen critical loads for ecoregions of the United States. Ecological Applications 21: 3049-3082.

Steltzer, H., and W. D. Bowman. 1998. Differential influence of plant species on soil nitrogen transformations within moist meadow alpine tundra. Ecosystems 1: 464-474.

Suding, K. N., J. R. Larson, E. Thorsos, H. Steltzer, and W. D. Bowman. 2004. Species effects on resource supply rates: Do they influence competitive interactions? Plant Ecology 175: 47-58.

Throop, H. L. 2005. Nitrogen deposition and herbivory affect biomass production and allocation in an annual plant. Oikos 111: 91100.

Van Miegroet, H. 2010. Assessment of nitrogen deposition and its possible effects on alpine vegetation in Grand Teton National Park. Changes $50 \mathrm{pp}$.

Vitousek, P. M., J. D. Aber, R. W. Howarth, G. E. Likens, P. A. Matson, D. W. Schindler, and D. Tilman. 1997. Human alteration of the global nitrogen cycle: Sources and consequences. Ecological Applications 7: 737-750.

Weathers, K. C., G. M. Lovett, G. E. Likens, and R. Lathrop. 2000. The effect of landscape features on deposition to Hunter Mountain, Catskill Mountains, New York. Ecological Applications 10: 528-540.

Williams, M. W., and K. A. Tonnessen. 2000. Critical loads for inorganic nitrogen deposition in the Colorado Front Range, USA. Ecological Applications 10: 1648-1665. 